\title{
左側頸部に発生した細網肉腫の電顕的観察
}

\author{
㚞 玉 香*.井上秀次郎*.豊田 弘*. 井上修二* \\ 藤田真知子* - 山下真一*. 朱雀直道* - 若江秀敏** \\ 沢熊芳生**.山本雅敏***
}

\section{Electron microscopic observations of reticulum-cell sarcoma in the area of the left neck}

\author{
Tamaka OKINA* - Hideziro InOUE* - Hiroshi ToyodA* - Shuzi INOUE* \\ Machiko Fujita* . Shinichi Yamashita* - Chokudo Sujaku* \\ Hidetoshi WaKaE** - Yoshio SawaKuma** \\ Masatoshi Yamamoto***
}

はじめに

われわれは先に下額左側臼歯部歯肉域に発現した，細 網肉腫の生検例について透過電顕的観察を行い報告した が1)，今回さらに左側頸部に発生した腫瘤で，リンパ腫 の疑いのもとに摘出手術を施行. 病理組織学的検索の結 果, 細網肉腫と診断された組織の一部を走査型ならびに 透過型電顕による併用観察の機会を得, 尰鈞組織の表面, 割断面像扰よび細胞構成成分などについて観察したので 追加報告する。

\section{症例並びに研究方法}

43才の男子症例. 左側頸部腫瘤形成を主訴として来科. 摘出手術を施行.

腫瘤組織は走查電影用には生理的食塩水にて 洗淮, 2.5\%緩衙グルタールアルデヒド溶液および，1\%緩衝オ スミウム酸溶液にて後固定, 上昇エタノール系列脱水, 酷酸イソアミル浸漬, 日立 HCP-1 型にて乾燥処理後 ${ }^{2}$, 金粒子のイオンスパッタリング蒸着を施し，電界放射型 走査顕微鏡 HFS-2型ならびに JSM-15A 型にて観察した. 一方, 透過電顕用には上記標本と隣接する残部組織を

* 久留米大学医学部口腔外科学教室 (主任: 朱售直道教授)

** 福岡科大学第 1 口腔外科学教室 (主任: 富岡德也教授)

*** 久留米大学医学部第 2 解剖学教室 (主任 : 村上正浩教授)

* Department of Oral Surgery, Kurume University School of Medicine (Chief : Prof. Chokudo Sujaku)

** First Department of Oral Surgery, Fukuoka Dental College (Chief : Prof. Tokuya Tomioka)

*** Second Department of Anatomy, Kurume University School of Medicine

(Chief : Prof. Masahiro Murakami)

受付：昭和51年 5 月 4 日
緩衝グルタールアルデヒドとオスミウム酸による 2 重固 定後，常法に従い脱水，エポン包埋を経て標本作製，薄 切後，酢酸ウランと鉛の重染色を施し，Hu-12AS 型な らびに JEM-100B 型にて観察した.

\section{観 察 所 見}

\section{光学顕微鏡的所見 (写真 1 2)}

$\mathrm{H}-\mathrm{E}$ 染色磦本では，腫瘤の表面は数層の薄い結合蟣 性の被膜で覆われ，その中央部の腫痬細胞は類円形ない し楕円形でやや淡明な核と弱い酸好性の細胞質を有し、 これらの細胞が密に組織内に増生してみられ, 腫湯内の 血管は硝子様を旺する（写真 1).

また鍍銀染色では腫湯細胞周囲には多量の好銀性を示 す細網線維が網工様あるいは樹枝状に配列している（写 真 2 ).

\section{走查電子顕微鏡的所見（写真 3 6)}

走查電顕的にも重瘤はその表面を薄い結合織性の被膜 で被われ，割断面切片では茞瘍組織は梁柱様構造を示す 小葉間結合組織で不規則に区分され，リンパ節の特徽を 暗示する基本的な構築像はほとんど認められず，その組 織内部は不規則に多方向へ配列する種々な形の腫湯緗胞 の集簇により小蜂窩状構造を呈している（写真3，4).

これらの腫湯細胞は一般に大小不同で集団的に或いは 数珠状に配列しており，細胞の形は円形，榇円形，扁平 様あるいは紡鍾形様など多岐にわたるが，なかです円形 ないし棈円形で径が約6～8 4 の大ささを示するのがすり とも多い，腫演細胞の表面には眯に配列する microvilli 様突起を有するもの, 或いは比較的平滑なるの,または盘 長い突起様構造を示すすのなど種々である（写直5，6). また腫湯細胞間には放射状，樹枝様または網状配列を 


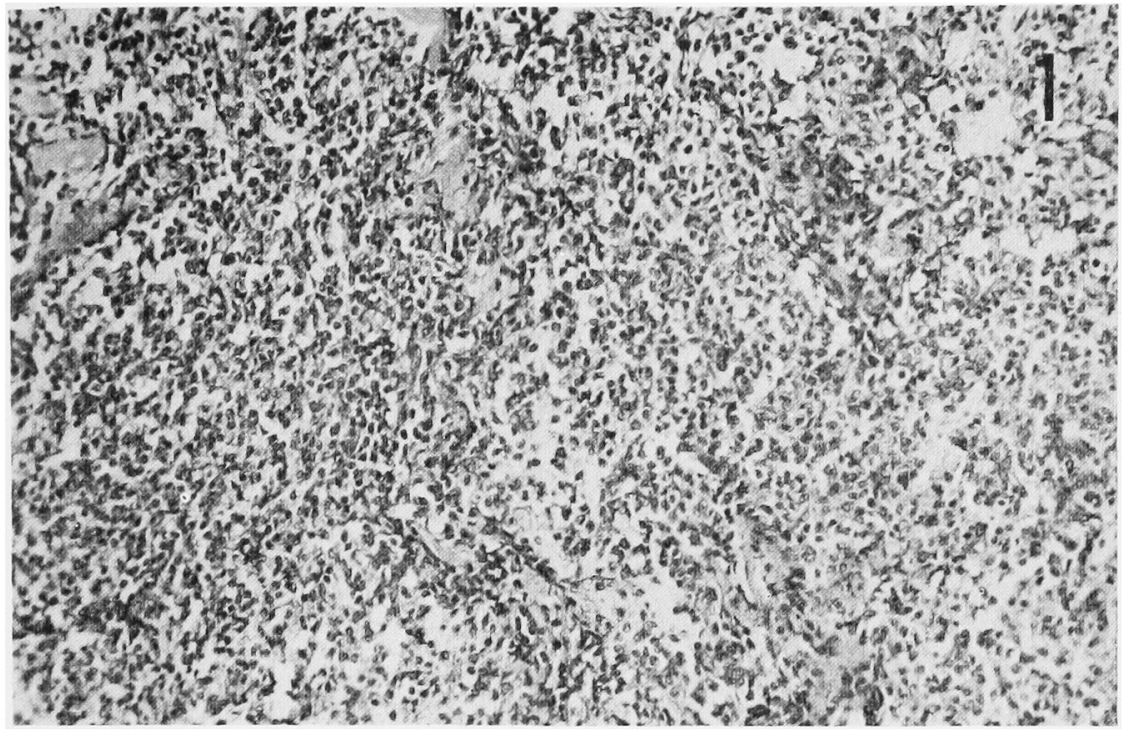

写真 $1 \mathrm{H}-\mathrm{E}$ 染色. $\times 100$

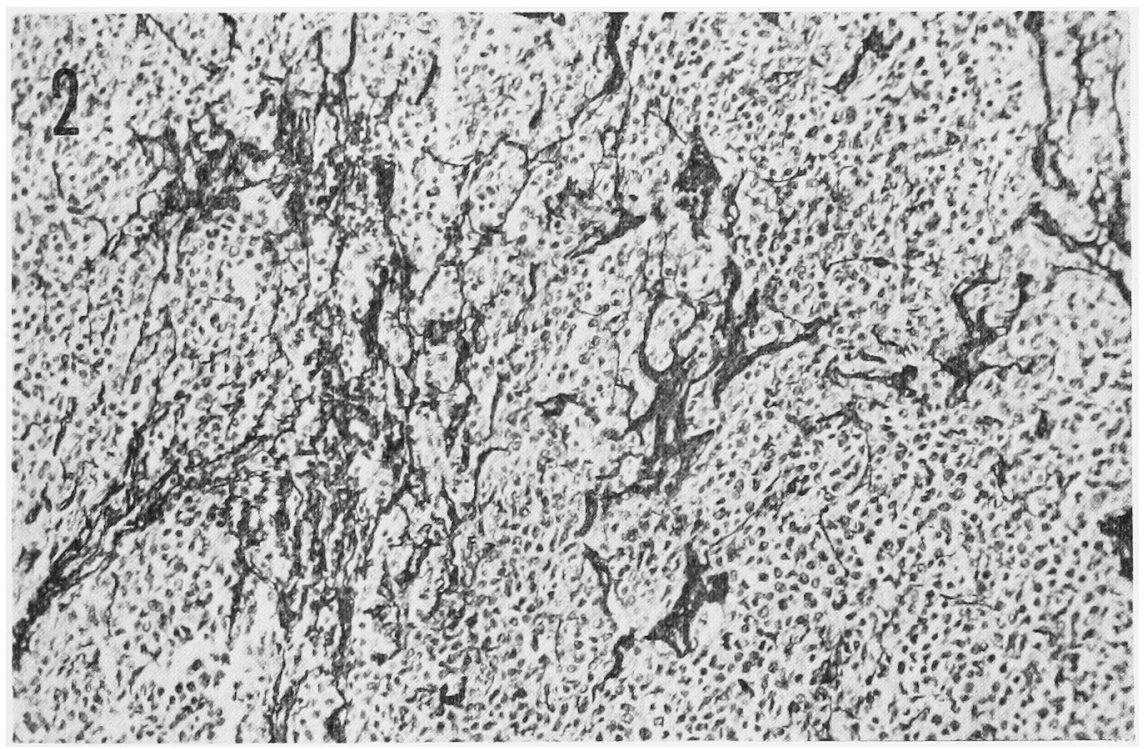

写真 2 鍍銀染色, $\times 100$

示す細網線維群が豊富に観察されるが，これらの細網線 維の多くは不規則に分布し，光顕標本です観察されたと 同様，時には庫湯細胞の周囲に密に接している（写真 5, 6).

透過電子顕微鏡的所見（写真 $7 \sim 9 ）$

透過電影的火す腫痬細胞は集団をなして認められ，こ れらの腫湯細胞群は明調を示す細胞と暗調を呈する細胞 から構成されている（写真 7〜9）. 腫湟細胞の形は円形 ないし棈円形，骰子形，不正形など種なな形を示すが， 一般に 6〜10 $\mu$ 径大のすのが多く主として明調を示す細
胞では核は細胞翼に比較して大きく，その形は類円形の ものから核膜の海入が著るしく不正形を示するのまで認 められる。

また胞体内小器官の発達は一様でなく, Golgi 装監, mitochondria，小管状の粗面小胞体，遊離の ribosomes, 中心子，種々な電子密度を示す小円形の構造物などが多 数存在するすのから，細胞質に比べ核の占める割合が大 きく，その周囲に僅かの小器官しか認められないるのや， 或いは細胞質の一部に小器官が偏在しているものなどが 多様にみられ，隣接する腫湯細胞の互いの間には統一性 


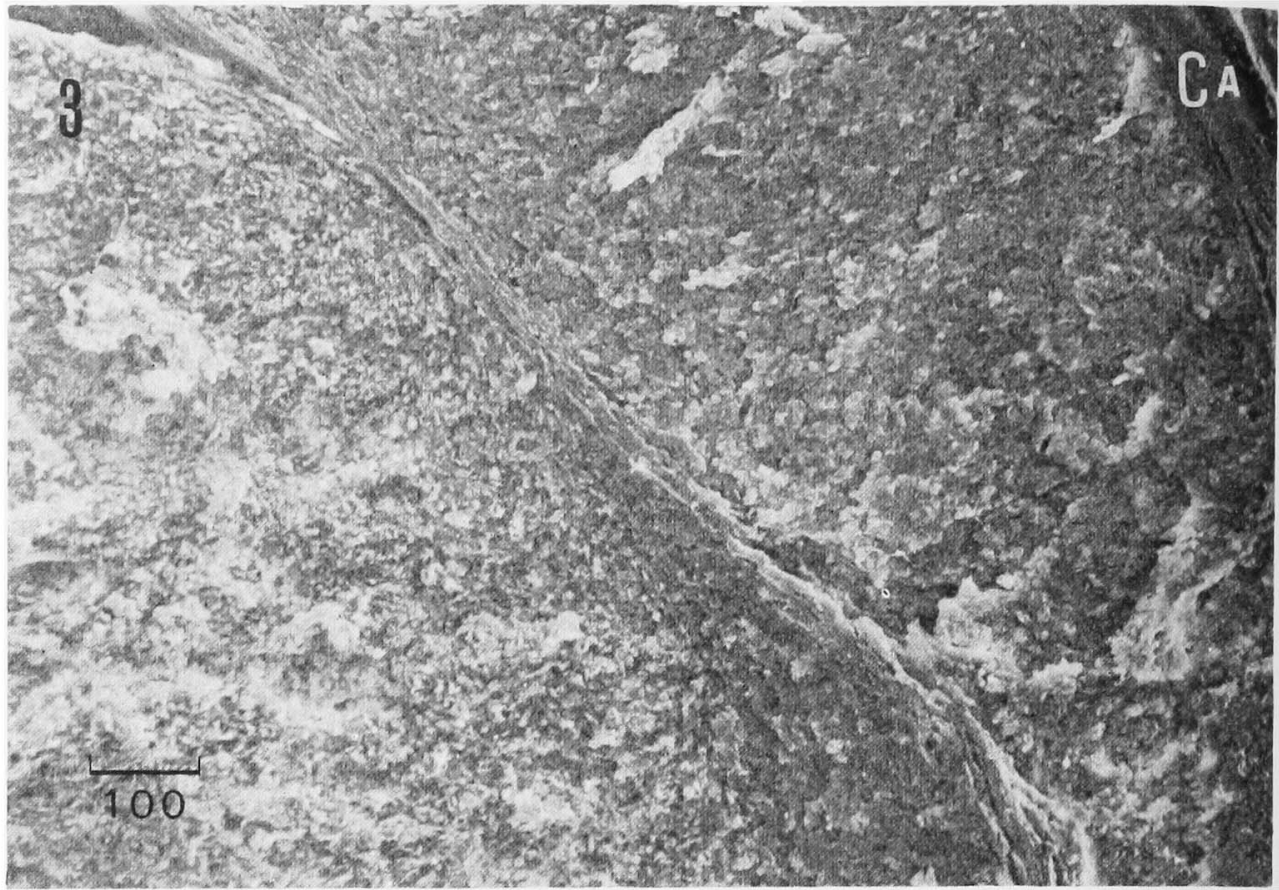

写真 3 腫瘤の概観像. 表面は被膜 (CA) で被われ, 胛演 組織は小葉間結合組織で区分される． ×150

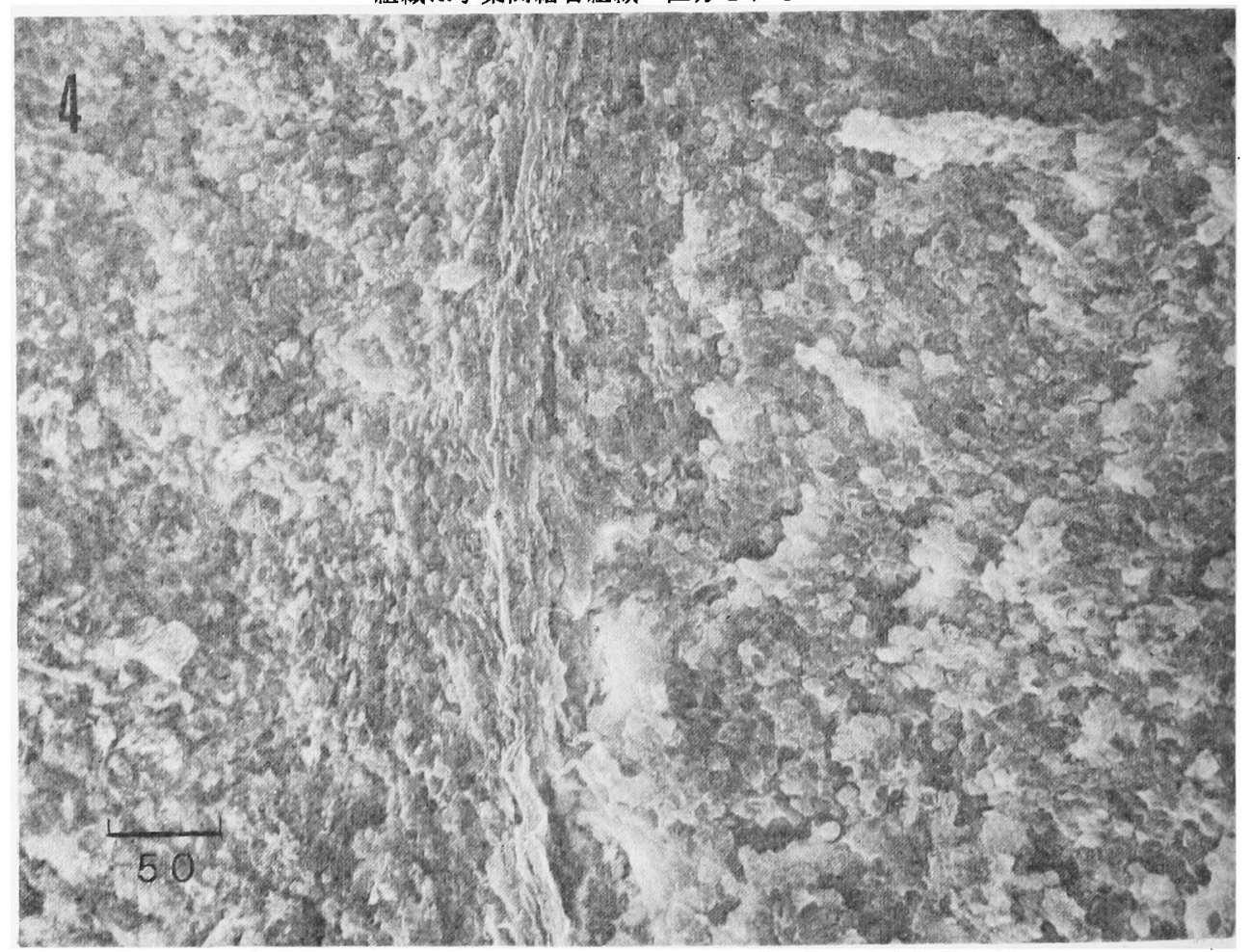

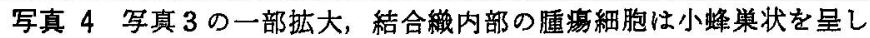

不規則な方向への增生を示している， ×300 


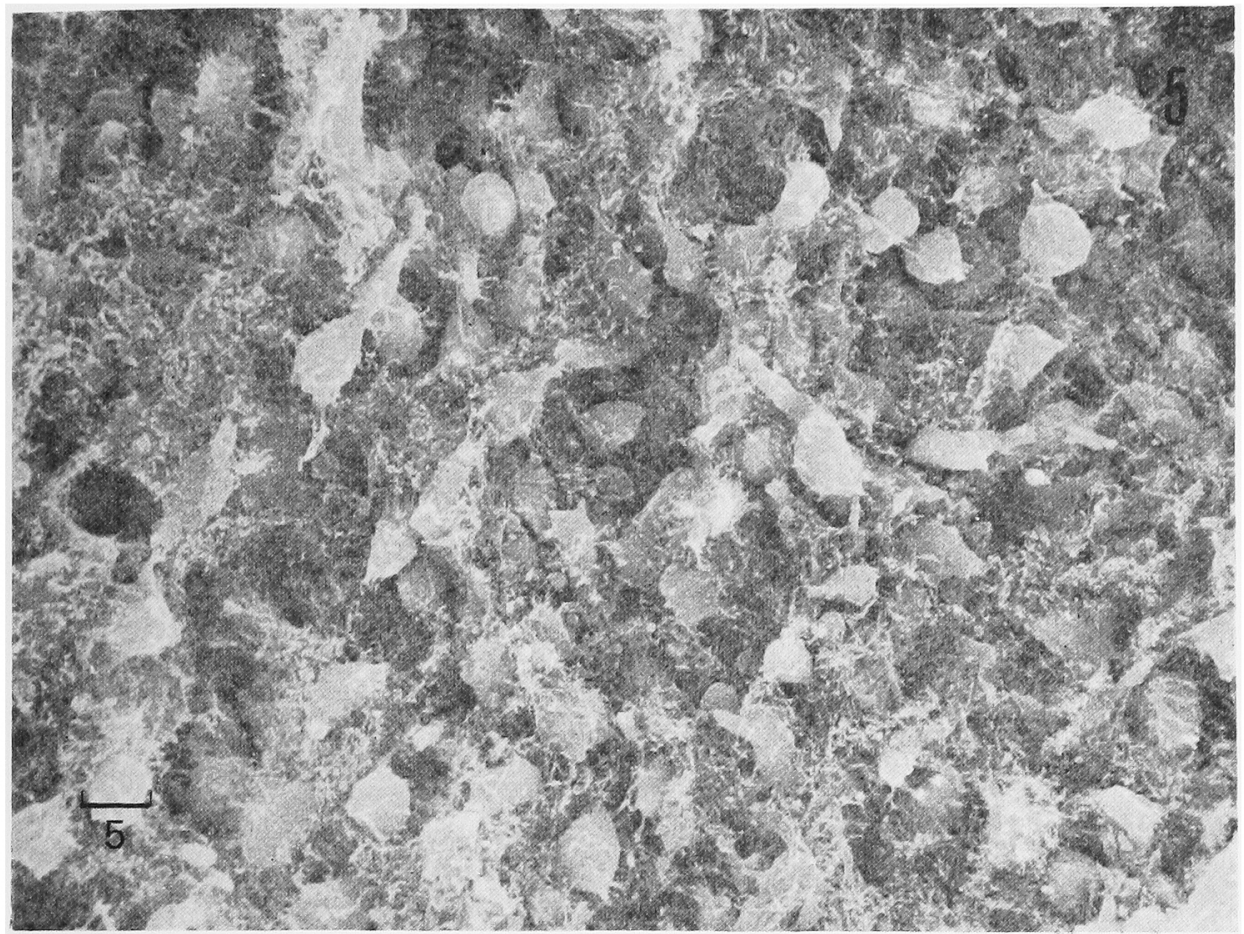

写真 5 種々な形を示す腫湟細胞群, 細胞間飞は豊富な

好銀線維が認められる， $\times 1,500$

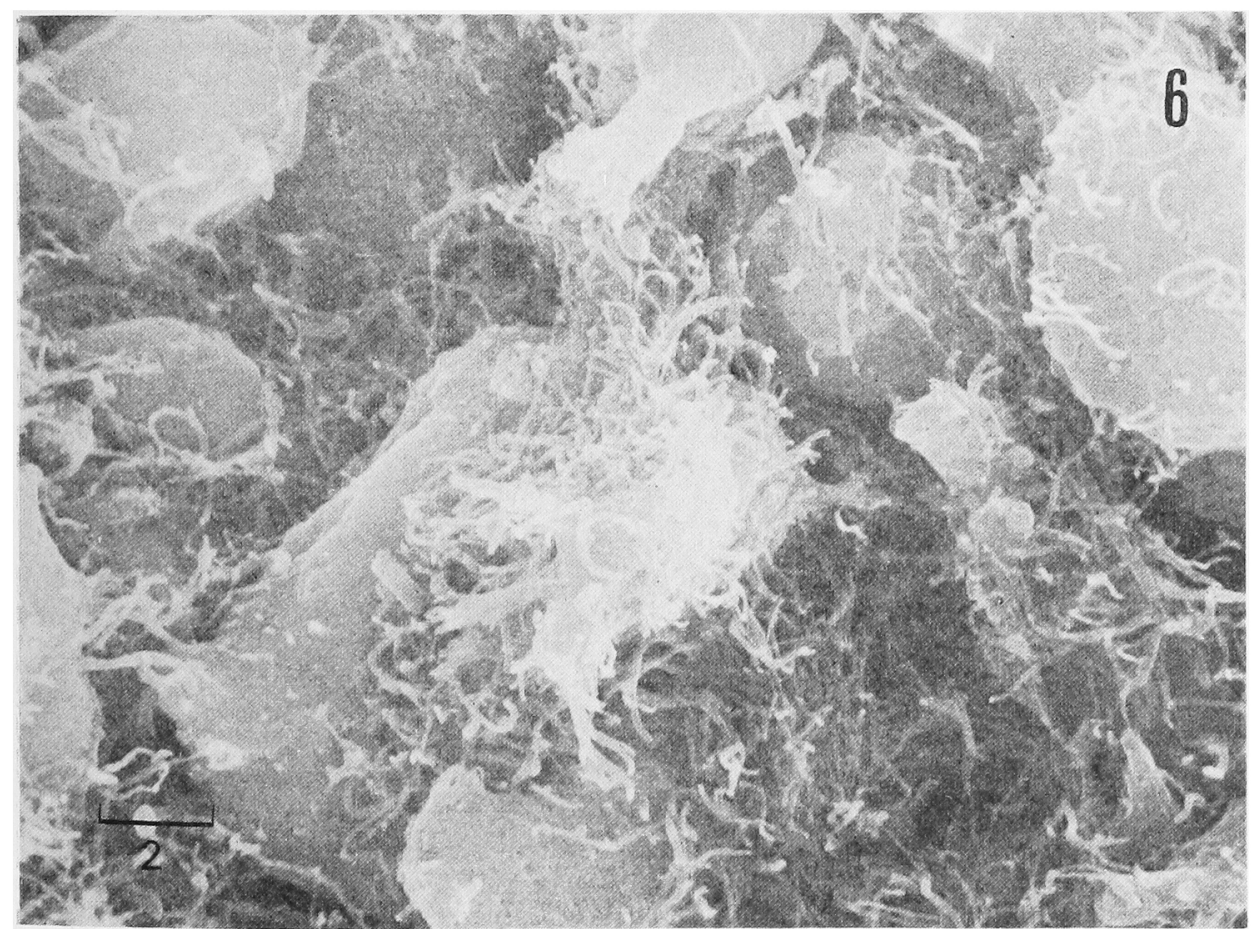

写真 6 円形ないし不正形の細胞が混在し，細胞表面に microvilli 様突起がみられる. 細胞間飞樹枝状配列を示す多数の細網線維が存在する. $\times 7,000$ 


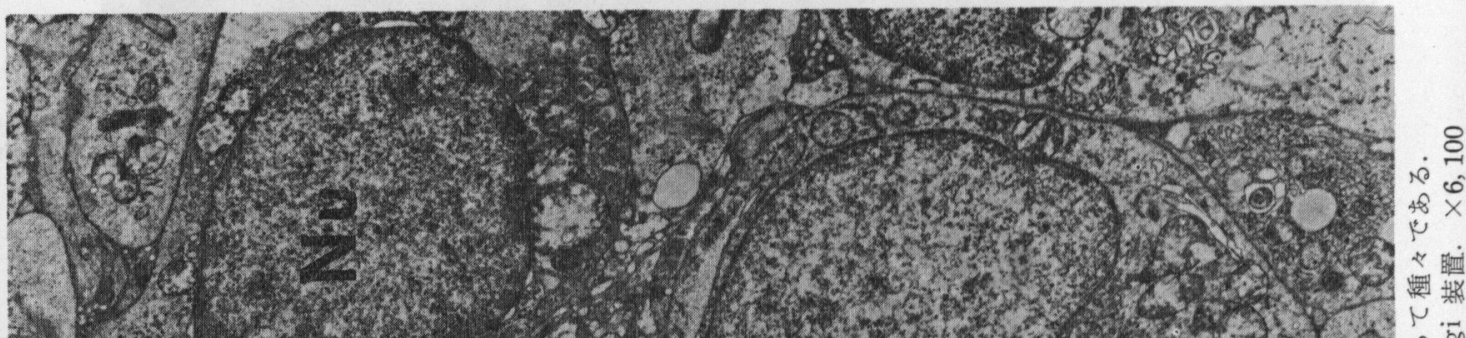

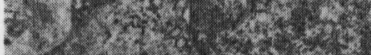

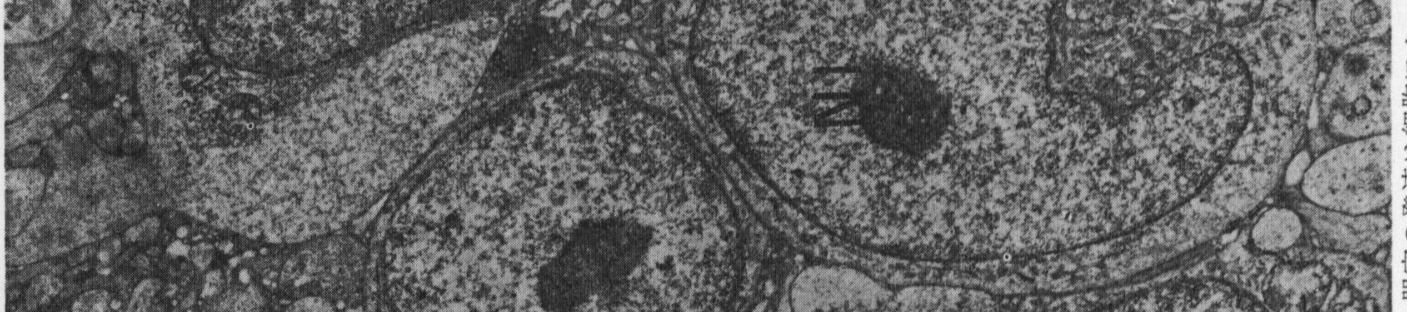

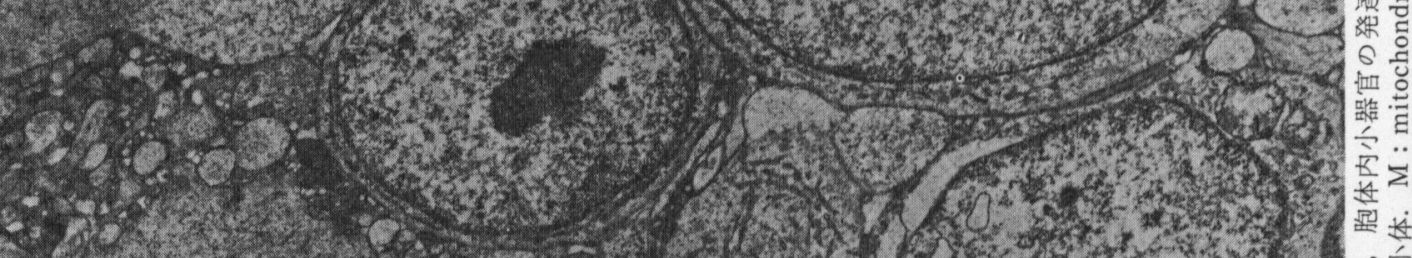

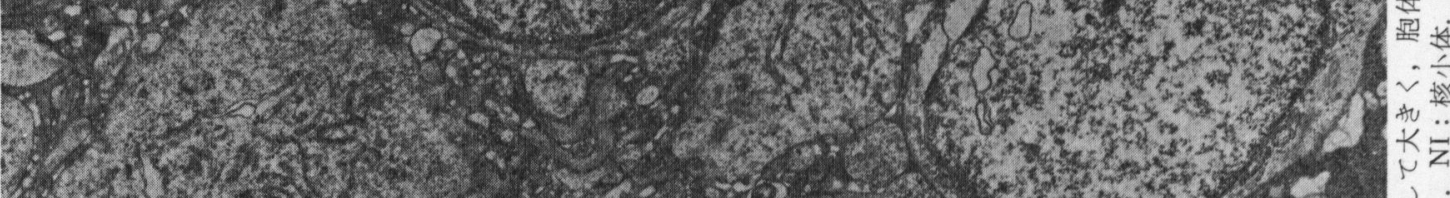

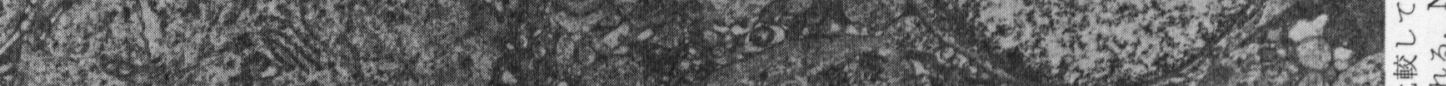

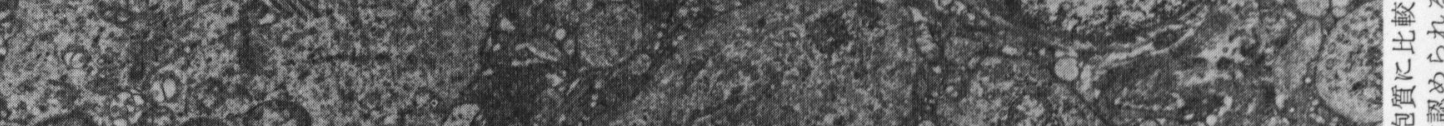

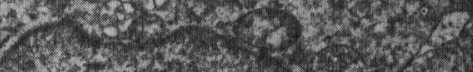

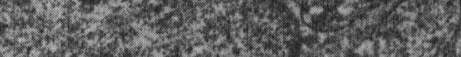

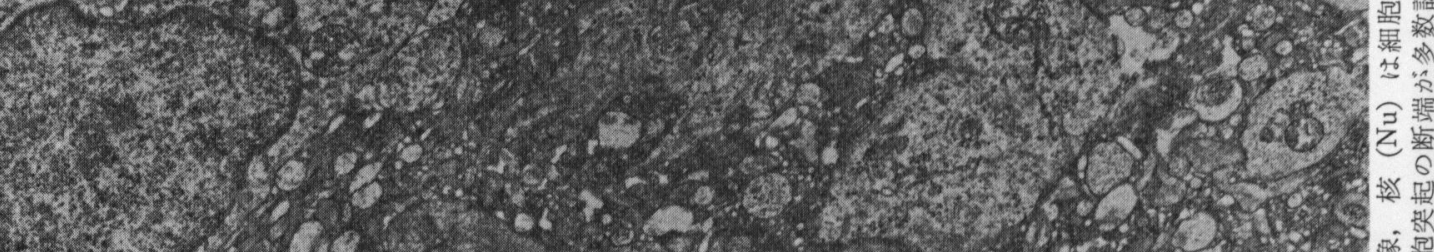

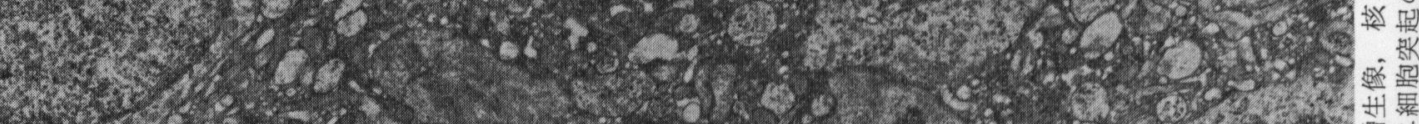

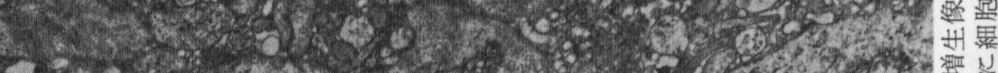
-

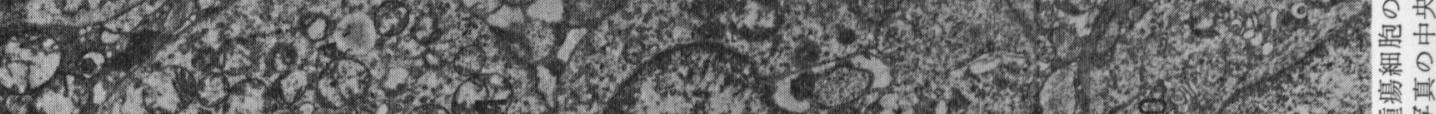

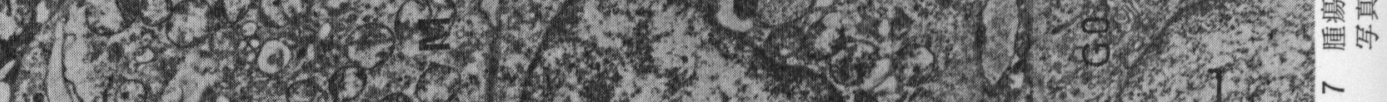

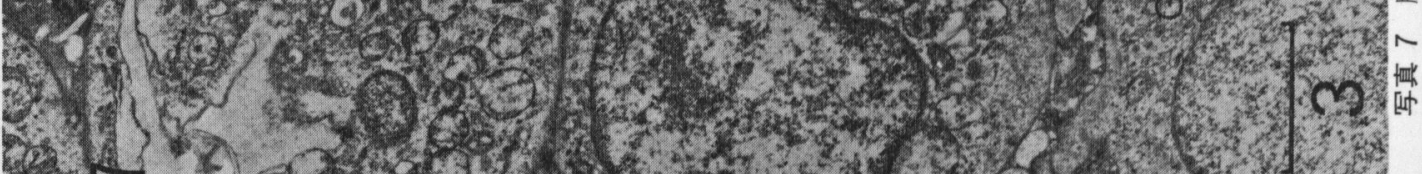

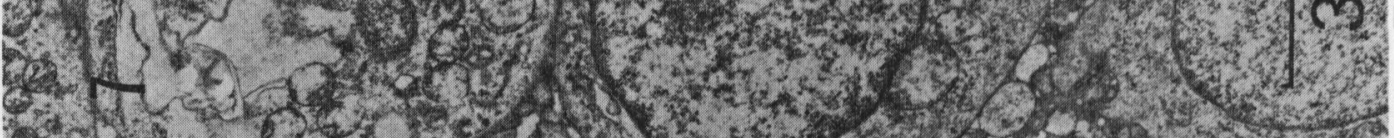

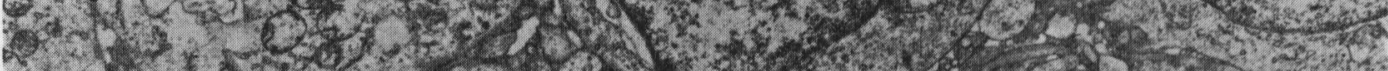
4h 


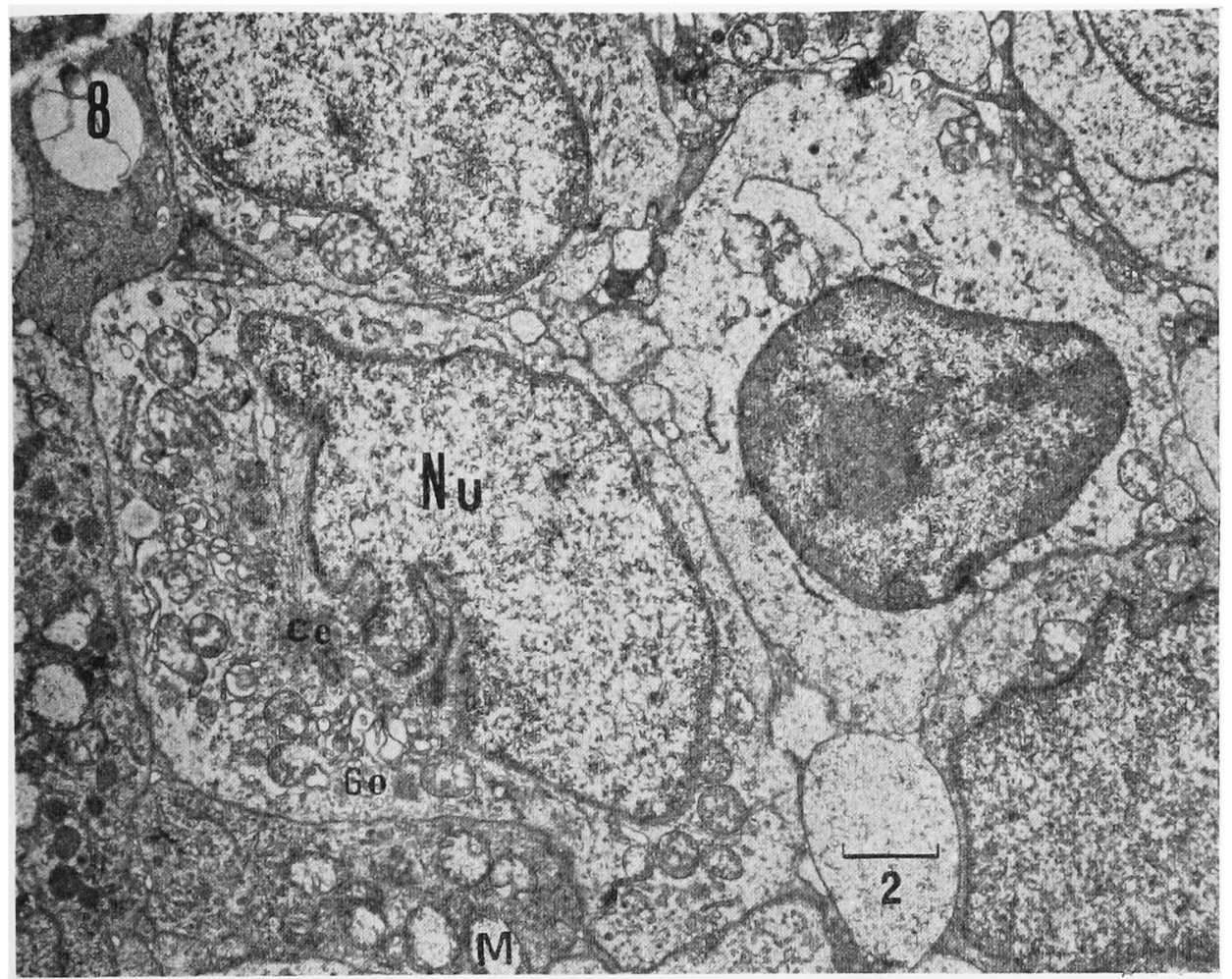

写真 8 隣接する腫湟細胞は規則性を欠き多様な形像を示す.

$\mathrm{Nu}$ : 核. Ce : 中心子. Go: Golgi装置. $\times 5,500$

が著るしく欠如しているのが特徴のように思われる.

尚、これらの腫瘍細胞は互いに平滑な膜面で接触する すののほかに，多数の細胞突起を持ったものでは，しば しば迷路様にかん合し（写真 7 の中央），場所によって は細胞膜の部分的な電子密度の増加と肥厚がみられる.

さらに上記の明調細胞の周囲に形は不正で核および細 胞質の電子密度が高く，暗調を呈する細胞が観察される が，当細胞は核ならびに小器官の構造が殆ど不鮮明なこ とから退行变性に近いもののよ5に思われる（写真 9）

上述の如く腫瘍細胞は互いに密に接触あるいは大小種 々の咨起様構造で, かん合するが，間質には膠原線維の 存在が認められこれらの膠原線維の多くは束状をなし て走行している。

\section{考按}

細網肉董は口腔領城に於いて発生する肉腫のなかでも， 比较的出現頻度は高く報告す多いが，当領域での電影的 観察は下䫇雪肉部に発生した，生検例についての，茂吕 らタおよびわれわれが経験した報告けをみるに過ぎない よらである。

また細網肉連は光学顕徽鏡による病理組織学的分類に は，赤崎の分類い)が一般的に用いられており，今日まで
に電顕的観察に基つく症例の多くは，この分類に従った ఠのが多い.

電顕的観察によると，リンパ小節は従来の報告では 基本的構築像が比較的明瞭に観察されるといわれてお $\eta^{5) 6)}$, 最近, イヌの 腸間膜のリンパ小節の内部構造を 三次元的に観察した，Fujita らクの報告によれば，洞を 構成する細胞成分のなかの細網細胞, 大食細胞, 形質細 胞およびリンパ球などについて観察し，各々の細胞はそ の形態学的特徽により鑑別し得ること，また細網細胞と 大食細胞の間には移行は認められないと述べ，リンパ小 節を区分する梁柱様構造は豊富な膠原線維と少数の弾力 線維を包括し洞内へ分枝しながら走行すると報告してい る.

われわれが本症例で観察した腫瘍組織は，前述の如く， 発達の悪い梁柱様構造で不完全に劃されており腫疡組織 は多方向へ増生する腫崵細胞で充たされ，イヌの腸間膜 や脾蔵などで今まで報告された明確な各種細胞8), 例え ば，リンパ球，形質細胞，大食細胞などの形像は示され ないが，断定は出来ないが細胞の形や大きさおよび細胞 内構造などから腫鹄細胞の多くは，細網様細胞であり時 折，リンパ球様細胞の基本的構造を遺残するものが混在 している様に思われる. 


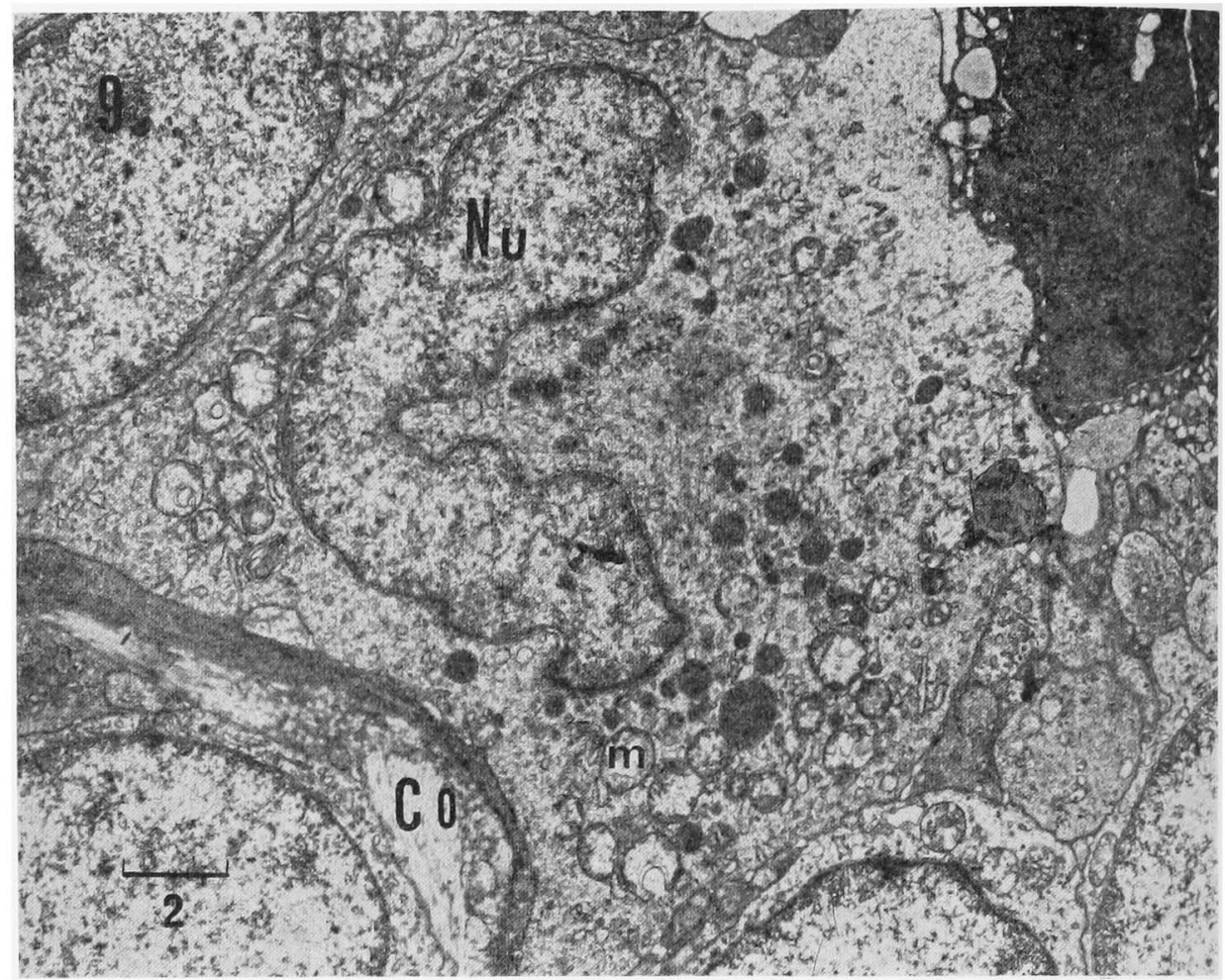

写真 9 分葉状を示す核 $(\mathrm{Nu})$ ，胞体内に高電子密度を示す多数の小円形の構造物のほか K, mitochondria (m)，小勂胞が存在する. 隣接細胞膜とは比較的平滑飞接して いる.閪質には琹原線維 $(\mathrm{co})$ がみられる．右上方は細胞变性像の一部. $\times 6,000$

他方，上述の病理組織学的分類を基準として，細網肉

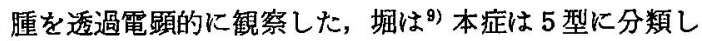
得たと言い，併わせて細網線維の本態ならびにその生成 機序についても解明を試みている.

また同様に細網肉腫を構成する各種細胞の同定を試み

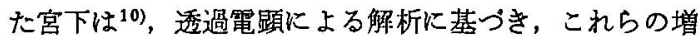
殖細胞群をその形態学的特徽から，細網細胞，リンパ型 細胞, 移行型細胞の 3 型に分類し細網肉腫症例中には多 数の移行型細胞が観察されたと報告している.

われわれが先に経騟した生検例の透過電 顕的観 察で は1)，腫痬組織は主として多数の明調な細胞群と若干の 暗調細胞より構成されておりこれらの腫瘍細胞の胞体 内小器官の発達程度は多様性が認められ，さらに可成り の頻度において，前期，中期に相当する有糸分裂像が観 られたことなどから，堀の四型に近いるのであろらと推 定した。他方，茂呂ら ${ }^{8}$ の覞察です，赤崎の網状型に一 致した運痬組織は明らかに，堀の分類では而型にほぼ該 当するものであったと迎べている。

しかしながら当症例の迗瘍組蟣は，先の生榆例とは発 生部位ならびに臨床経過も共に著るしく異なり，瘇瘤形 成による障害などを患者は自覚しなかった症例である。
摘出手術により得られた当腫瘍は光学的ならびに透通 電䫓的にも，いわゆる今日では一般に悪性尰場像として 報告されているものとほぼ同様の多彩な所見を呈して扰 り，われわれが先に経験した生険例の症例上りる分化度 は低く，腫湯細胞の同定についても必ずしす容易汇法行 い得ず，また胿盛な細網線維の生成を示唆する像怡殆ん どみられなかったが，三次元的な像との併用䚋察により 当組織は形態学的には比較的, 細絪細胞に近い type の るのと思われ，上述の所見から今後さらに経過観察を必 要とする症例と考古られる。

\section{ま と め}

43才の男子の左側頸部に発生した，細網肉腫を走型 ならびに透過型電顕の併用観察を行い次のよらな所見を 得た.

（1）走查電顕的には腫瘍組織は小葉間結合組織块 分され，その内部は増殖した腫瘍細胞により小蜂察状情 造を示している.

（2）腫湯紐胞は大小不同，種々な形を呈するが，な

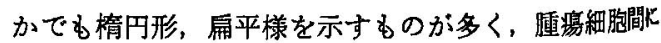
は不規則に各方向へ走行する豊富な細網線維が浔められ 
ろ.

（3）透過電顕的にも腫瘍細胞は集簇をなして観察さ れるが，一般に 6〜10 $\mu$ 径大のものが多く主として核原 形質比が大きく, 胞体内小器官の発達程度は種々で多様 性がみられる.

（4）钽細構造レベルでの検討から, 当腫瘍組織は細 網細胞由来を窥わせるるののように思われる。

(本論文の要旨は, 昭和50年 7 月25日, 第13回福岡歯 科大学学会例会ならびに昭和 50 年 9 月 27 日, 第20回日本 口腔外科学会総会に於いて報告した。)

（御指導，御校閲を睗わった，久留米大学医学部第 2 解剖学教室, 村上正浩教授に謹んで深甚の謝意を表しま 才.

また終始御鞭撻, 御援助を頂いた，冨岡德也教授に厚 くお礼申しあげます.）

文献

1）翕玉香, 他: 細網肉腫の電子顕微鏡的観察. 口 科誌 $22: 451973$.

2) 田中敬一：医学生物学領域における現状と展望.
一特集走査電子顕微鏡 II一 細胞 $7: 21975$.

3）茂呂周，他：歯肉に発生した細網肉腫の 1 症例 光顕ならびに電子顕微鏡的観察. 日大歯学 47 : 6241973.

4）赤崎兼義：網内系腫湯. 日本血液学全書， 5 , 白血 病. 第 1 版, 丸善, 東京, 1961，386面.

5）坂口弘, 他編：生物界の造形, 走査電子顕微鏡 写真集. 第 1 版, 講談社, 東京, 1971, 63頁.

6）今井大，松田幹夫：リンパ節の正常とその病的 変化（2）正常構造と構成細胞（1）。皮穈臨床 $16: 6391974$.

7) Fujita, T. et al. : Scanning electron microsccpe observation of the dog mesenteric lymph node. Z. Zellforsch $133: 1471972$.

8) Fujita, T., Tokunaga, J. : Scanning electron microscopy in histology and cytology. Yamada, E., et al. Recent progress in electron microscopy of cell and tissues. led, Igaku Shoin, Tokyo, 1976, p. 319.

9）坭太憘夫：細網肉腫の電子顕微鏡的研究. 米子 医誌 $16: 2811965$.

10）宮下 学：悪性リンパ腫の電子顕微鏡的研究. 慈 医誌 $82: 741967$. 